\title{
A INFLUÊNCIA DA MÍDIA NA CONSTRUÇÃO DE ÍDOLOS ESPORTIVOS PARA OS JOVENS
}

DOI: 105902/0102830813182

Data de Submissão: 17/03/2014 Data de Aceite: 17/07/2014

Victor Valdez Dantas Azevedo
Universidade Federal de Sergipe
Aracaju/SE/Brasil
vvazevedo@yahoo.com.br

Cristiano Mezzaroba

Universidade Federal de Sergipe

cristiano_mezzaroba@yahoo.com.br

Fabio Zoboli

Universidade Federal de Sergipe

zobolito@gmail.com

RESUMO: Amídia enquanto agente político tem a capacidade de gestar comportamentos, pensando assim partimos da necessidade de observar o quão influenciáveis são os jovens quando pensamos em relação à idolatria esportiva. Neste sentido, o objetivo deste estudo foi analisar a possível influência midiática na construção de ídolos esportivos e como são percebidos no universo dos jovens. Para tal foram selecionados para a pesquisa alunos do $1^{\circ}$ e $2^{\circ}$ ano do Ensino Médio de uma escola pública federal de Sergipe. A partir dos resultados obtidos, percebemos que, mesmo se tratando de um colégio onde a mediação pedagógica é muito importante para entender e discutir as questões que envolvem a mídia, verificamos um forte poder simbólico midiático, incorporando significados mercadológicos na relação clube-ídolo-torcedor que impactam também na questão corporal.

Palavras-Chave: mídia; ídolos esportivos; espetacularização esportiva; jovens. 


\section{Introdução}

A mídia é o principal meio de entretenimento e comunicação em grande escala do mundo. Ela é capaz de criar grupos sociais, influenciar no que vestir, comer, assistir, e até mesmo o que seguir como forma de vida (FAUSTO NETO, 2002). Além do rádio e da TV, as mídias impressas (jornal e revista) e as novas mídias (internet, redes sociais) formam as principais mídias existentes.

O poder midiático necessita sempre estar gerando algo que o sustente e torne lucrativo, dando continuidade à sua atual situação. Influenciar o sujeito é a principal forma de manter e conseguir que eles não o esqueçam, ele tem a capacidade de criar mudanças que podem influenciar as pessoas, por isso nada que esteja na mídia é ingênuo e totalmente verdadeiro (FERRES, 1996). Com isso, devemos aprender a entender a mídia e as formas como tendem a produzir e circular as notícias e seus conteúdos.

Em geral, a mídia acaba gerando uma espetacularização ${ }^{1}$ para chamar mais atenção do público na necessidade de reforçar seus discursos e imagens. O que em uma emissora é veiculado como algo normal ou banal, em outra pode dar uma dimensão absurda pela necessidade de ver a tudo e a todos, ali como uma forma rentável de se estabelecer uma relação (KELLNER, 2006).

Segundo Betti (1998), a criação desta espetacularização vinculada ao esporte se deu devido ao espectador pagar para assistir, mas a partir dos anos 1960 é que inicia o "ao vivo", iniciando assim a fase de telespectadores e a necessidade de sempre estar produzindo para o público notícias novas, e a falação esportiva² é a forma mais perpetuada. Assim, percebemos que o esporte passa a ter características midiáticas, tornando-se o "esporte da mídia" e não mais o "esporte na mídia", pois elas acabam reformulando e criando novas ideias para que o esporte ganhe mais espaço, gerando maior visibilidade e lucro (BETTI, 2001).

A internet e as novas mídias aparecem como as novas formas de perpetuar essa falação esportiva. Antigamente era necessário tentar entrar em contato com clubes e atletas para ter informações. Muitas vezes as notícias, hoje, chegam através das redes sociais e, como 1 Termo criado por Guy Debord, que afirma: "Toda a vida das sociedades nas quais reinam as modernas condições de produção se apresenta como uma imensa acumulação de espetáculos. Tudo o que era vivido diretamente tornou-se uma representação" (DEBORD, 1997, p.13).

${ }^{2}$ Conceito oriundo de uma crônica de Umberto Eco, escrita em 1969. 
cita Rebustini et al (2012, p. 71), "O esporte, juntamente com o universo do entretenimento, tem feito uso regular dessas novas tecnologias, inicialmente por meio dos sites dos clubes ou dos próprios atletas, e nos últimos anos com a utilização sistemática das redes sociais."

Logo, os eventos passama terproporções e conotações gigantescasea espetacularização esportiva vê nos atletas formas de perpetuar o esporte com uma rentabilidade enorme para as empresas e para a mídia. A partir disso, existe a necessidade da criação de ídolos e atletas que se destacam, os quais acabam tendo uma maior repercussão na mídia, gerando sempre novos ídolos para que não se acabe essa repercussão sobre o esporte e seus acontecimentos (MEZZAROBA; PIRES, 2010).

A "personificação" do ídolo acaba gerando todo um atrativo para citar a competição ou o esporte que tem a ver com ele. Na Copa do Mundo de 2002, além do olhar do técnico que criou uma "família" entre os jogadores, a mídia criou uma expectativa no "trio de erres" formado por Ronaldo, Rivaldo e Ronaldinho para que pudessem chamar a atenção dos telespectadores (ASSIS; VIEIRA, 2003). Essa necessidade de sempre ter um ídolo despontando acaba fazendo com que a mídia procure atletas que estão se destacando para uma tentativa de "acerto", muitas vezes chegando a recorrer a ex-ídolos.

Entendemos que os jovens também fazem parte desta "globalização midiática" e que estão em constante interação com as notícias produzidas e veiculadas pelo conjunto de veículos midiáticos. Portanto, temos como ponto de partida nesta investigação: a partir de um grupo de jovens, qual a possível influência da mídia na criação dos ídolos? Além disso, o objetivo principal desta pesquisa foi analisar a possível influência midiática na construção de ídolos esportivos e como esses possíveis ídolos são percebidos no universo dos jovens no contexto escolar.

Sendo assim, fomos a campo investigar duas turmas de jovens do Ensino Médio do Colégio de Aplicação (CODAP) da Universidade Federal de Sergipe (UFS) do campus de São Cristóvão. O Colégio de Aplicação foi criado em 30 de junho de 1959, ligado à Faculdade de Filosofia de Sergipe, funcionando somente com séries ligadas ao Ensino Fundamental, sendo que só em 1965 é instaurado no CODAP o Ensino Médio. Em 1968 é criada a Universidade Federal de Sergipe e o Colégio de Aplicação e a Faculdade de Filosofia de Sergipe são acoplados a ela. 
Atualmente, o CODAP atende cerca de 470 estudantes de Ensino Fundamental e Médio e, a exemplo da UFS, tem suas práticas ligadas à tríade ensino, pesquisa e extensão. CODAP tem uma função importante no contexto da UFS na medida em que as turmas do colégio servem como local de estágio dos mais variados cursos de licenciatura que a Universidade oferece.

\section{Procedimentos Metodológicos}

O presente texto é fruto de uma pesquisa de cunho quali-quantitativo. O viés qualitativo se justifica pois a interpretação dos fenômenos e a atribuição de significados dados a eles são centrais em nossa pesquisa quando buscamos identificar como a mídia constrói os sentidos ao "arquitetar" ídolos junto aos jovens pesquisados. No entanto, imbricado a isso manipulamos dados coletados na forma de cálculos e estatística descritiva básica a fim de quantificarmos os dados analisados.

Sob este viés, Neves (1996, p.2) menciona que a junção dos métodos qualitativos e quantitativos tem como possibilidade "congregar controle dos vieses (pelo método quantitativo) com compreensão da perspectiva dos agentes envolvidos no fenômeno (método qualitativo)".

O instrumento de coleta de dados da pesquisa se deu a partir da aplicação de um questionário com onze questões, com perguntas mistas, a duas turmas do Ensino Médio (uma do $1^{\circ}$ e outra do $2^{\circ}$ ano) de uma escola pública federal de Sergipe, localizada em São Cristóvão. Neste sentido, compactuamos com Gressler (2007, p.167) quando anuncia que "o questionário é constituído por uma série de perguntas, elaboradas com o objetivo de se levantar dados para uma pesquisa, cujas respostas são formuladas por escrito pelo informante, sem o auxílio do investigador".

No retorno das respostas do questionário com os alunos, entendemos que se necessitava, ainda, de um maior esclarecimento quanto a algumas questões e dúvidas que inicialmente não visamos encontrar. Por isso, em um segundo momento foi aplicado um questionário com duas professoras, com seis questões abertas e de abordagem qualitativa, por isso entendemos que elas também foram sujeitos da pesquisa. 
Os sujeitos da pesquisa foram escolhidos devido à faixa etária propiciar um maior entendimento sobre as características midiáticas em relação aos seus possíveis ídolos. Por isso escolhemos essas turmas: por terem uma participação maior nas redes sociais e, em sua grande maioria, terem acesso à internet.

Os dados foram organizados a partir da descrição dos próprios dados encontrados nos questionários respondidos pelos sujeitos da pesquisa. Estão organizados e tratados a partir da estatística descritiva básica, neste caso apenas a análise percentual, com a elaboração de gráficos para visualizar os dados encontrados e, em seguida, realizar uma análise qualitativa dos mesmos.

\section{Apresentação E Análise Dos Dados}

Organizamos este subtópico com o intuito de apresentar as relações das respostas dos alunos pesquisados com os objetivos traçados, recorrendo à literatura pesquisada para a discussão dos dados aqui apresentados. Participaram da pesquisa 40 (quarenta) alunos, sendo dezoito alunos do primeiro ano do ensino médio, na faixa etária entre 14-15 anos (10 meninos, 8 meninas), e vinte e dois alunos do segundo ano do ensino médio, na faixa etária entre 15-18 anos (10 meninos, 12 meninas). Os dados aqui analisados foram agrupados, ou seja, correspondem a uma percepção do total deste grupo de jovens, não sendo feita diferenciação entre primeiro e segundo ano.

Dentre os alunos envolvidos na pesquisa, uma aluna afirmou que não gostava de esportes e creditou esta afirmação ao fato de não assistir televisão, os outros que mantiveram a negação identificaram isto com fato de não "se movimentar", falando sobre ser sedentário ou não gostar de exercícios físicos. Os que afirmaram gostar do esporte citaram que o gosto pelo esporte se dava pela "diversão", "faz bem pro corpo", "identificação”, "entretenimento", "porque nasci no Brasil (país do futebol)", "bom para o crescimento e a mente", "vida mais saudável", "exercitar o corpo", "me sinto feliz", "distração".

Percebendo isso, entendemos que, de certa forma, a influência do esporte moderno está cada vez mais associada à saúde e ao físico, pois se credita ao "corpo belo" os bons desempenhos dos atletas, conforme Bianchi e Hatje (2006). Além disso, uma das respostas 
nos mostrou o que o aluno entende da relação esporte $x$ mídia, ao definir que gosta de esporte "porque cria ídolos", o que demonstra estar inteiramente incluso no discurso midiático sem a devida percepção de tal entendimento.

Logo, identificamos que a relação entre o esporte e a televisão está cada dia mais perceptível, seu crescimento acontece devido ao maior espaço na mídia para apresentar competições ao público e espetacularizá-las para que atraia cada dia mais telespectadores.

A grande maioria dos alunos citou o voleibol como o esporte mais praticado. O segundo mais votado foi o futebol e, posteriormente, a natação e o futsal. Outros esportes que foram mencionados pelos sujeitos pesquisados foram o handebol, o basquete e o atletismo. Andar de bicicleta, dança, tênis, luta, a GR (ginástica rítmica), MMA (mixed marcial arts), sinuca, vôlei de praia, corridas automotivas, pular corda, ciclismo, muay-thai e jiu-jitsu, embora citados, o foram com menos expressão.

Perceber o voleibol como o esporte mais praticado nos levou a uma inquietação em tentar entender o porquê de o futebol ter sido superado por este grupo específico pesquisado, já que o futebol é o mais midiático e reconhecido como primeiro esporte no Brasil e no mundo. Ao fazer o questionário com as professoras da instituição, uma delas nos deu como resposta: "Não existe trabalho específico com voleibol, em algumas turmas este conhecimento foi trabalhado, mas em uma unidade de ensino" (PROFESSORA B).

É evidente o crescimento do voleibol no Brasil diante de tantas conquistas recentes. Essas vitórias acabam por buscar ainda mais espaço na mídia, percebendo ali uma forma de entreter o público, por isso sofrem mudanças que ocasionam em formatos possíveis de aparecer, principalmente na televisão, configurando assim uma "propriedade" dos que assistem, como percebemos em Marchi Junior (2005, p.159).

Podemos entender também que o voleibol, atualmente, tem sido alvo de mudanças para que a referida modalidade tivesse um lugar cada vez maior na mídia, concomitantemente tornando-se mais popular. Como identificamos mais claramente na citação de Pinheiro (1995) citado por Marchi Junior (2005, p.153-154) ao retratar uma fala do então presidente da CBV, Carlos Arthur Nuzman: "Eu prefiro um ginásio vazio com transmissão da televisão a um ginásio cheio, sem televisão. O vazio atinge milhões de telespectadores em todo o país". 
Além disso, uma grande variedade de esportes foi citada. Novamente em contato com a professora, ela informou que os profissionais de Educação Física (EF) do colégio visam trabalhar com a maior variedade de esportes possíveis, principalmente com os que são "esquecidos" pela mídia, visando não somente o lado de conhecê-los, mas também tornar os alunos críticos para ter a percepção de tudo que os envolve, como preconceitos, relações de poder, o lado financeiro, midiático. Segundo a Professora A: "buscamos sempre a tentativa de trazer coisas desconhecidas dos alunos, para se tratar das questões que o envolvem, como a capoeira e suas discussões. Trabalhamos sempre preocupados na formação do sujeito para se inserir socialmente".

E cita ainda que ficou muito feliz por ver essas respostas, pois entende que o seu trabalho está dando frutos, por não aparecerem somente os esportes que mais são abordados na mídia. Em confronto com os resultados anteriormente discutidos, fica visível que nem sempre a mídia, isoladamente, é capaz de influenciar os alunos; a EF também tem seu poder de mediação e influência - na figura do seu responsável, o professor - com o objetivo de trabalhar questões pedagógicas com os jovens.

Percebemos que na necessidade de apresentar essa grande quantidade de esportes e criar esses debates e torná-los críticos com relação aos esportes em geral, pode-se acabar caindo na polissemia, como encontramos em Betti (2006), que com a espetacularização midiática no esporte acabou multiplicando e criando novas práticas corporais devido à necessidade de apresentar novidades e facilidades de aceitação ao público, gerando assim práticas que fogem da definição clássica de "esporte" pela Sociologia do Esporte, como percebemos na escolha de sinuca e dança como esportes pelos jovens pesquisados.

Concluímos aqui que esta escola é perpassada pelas mudanças que ocorrem na EF Escolar atualmente. Concordamos com a ideia de Bracht (1999) que, independente de qual teoria pedagógica se assemelhe, os professores tentam diferenciar o "esporte moderno" do "esporte educacional", que busca criticizar o aluno e não somente reproduzir o esporte de rendimento.

Para melhor análise dos gráficos que apresentaremos na sequência, podemos adiantar que os valores colocados identificam o valor absoluto, ou seja, do número de alunos que responderam ao questionário. 


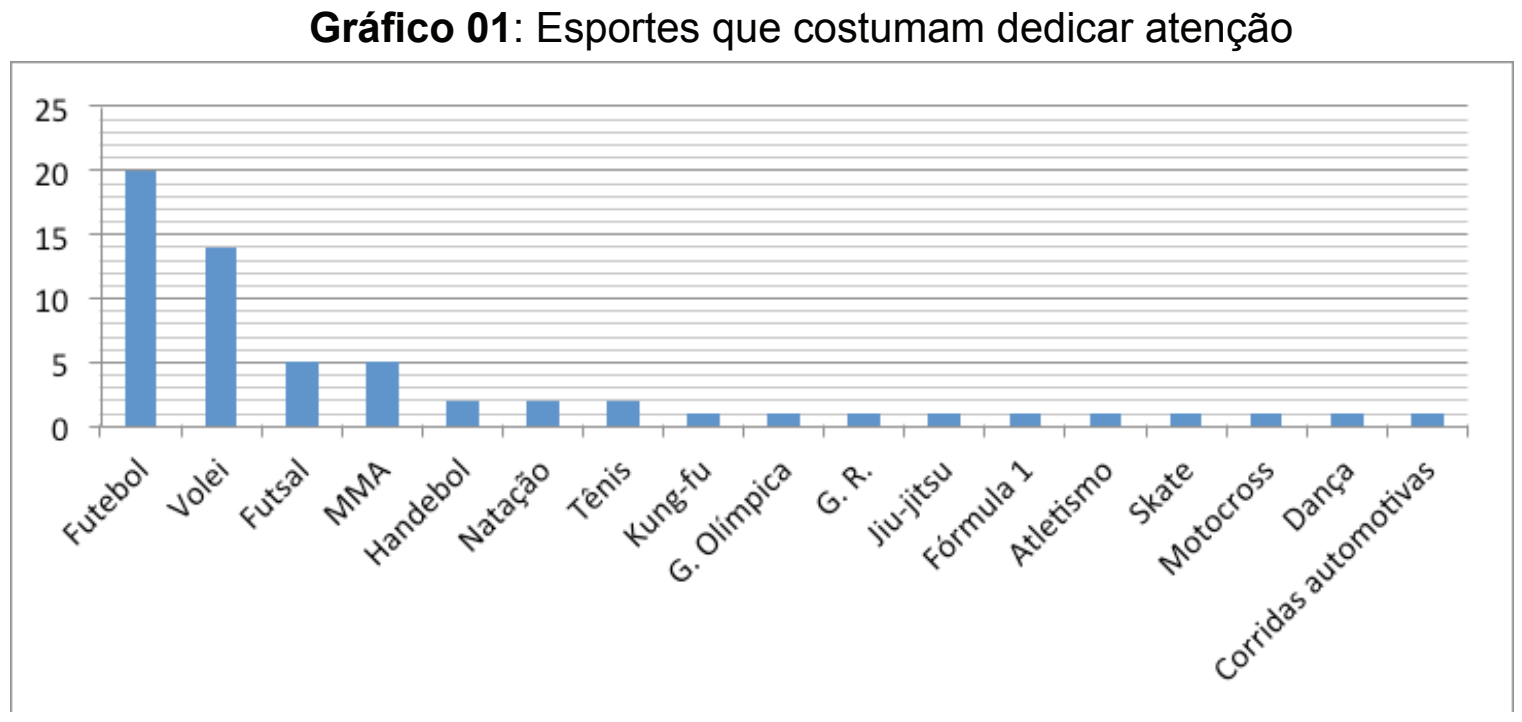

Entre os alunos, nesta questão, houve uma inversão das respostas quando comparado ao esporte mais praticado. Percebe-se que o futebol é o mais citado, com 20 votos, e o voleibol fica em segundo, com 14. Esse gráfico mostra o que encontramos em Sanfelice (2001, p.2) sobre como a mídia influencia nos esportes devido à relação de oferta-demanda existente. Ao indicar e propiciar a ideia de que o Brasil é o "País do futebol", começa a cada vez mais tentar manter essa identificação e disponibilizar mais espaço na mídia para esse esporte, pois a cada dia que passa se torna mais lucrativo e rentável para os principais envolvidos.

Consideramos essa reflexão e constatamos que a mídia procura cada vez mais atrair as atenções do público, pois, como afirma Gastaldo (2009), ela sempre cria novas formas de prender a atenção dos espectadores. Com o futebol podemos perceber a evolução e o constante aparecimento de novas formas de apresentar o jogo para todos. Na televisão, principalmente, a cada dia se investe mais, tanto que, na Copa das Confederações (2013), quem assistia pela "TV Globo" percebia o alto investimento colocado ali, principalmente no quesito "tecnologia" de transmissão e de geração de conteúdos nos intervalos dos jogos.

Quando perguntados sobre se tinham algum ídolo esportivo, tanto no primeiro quanto no segundo ano houve mais afirmações neste sentido da parte das alunas, em comparação os alunos. A principal diferença que se pode notar é que as meninas escolhem essa idolatria não somente pelo aspecto de performance esportiva do atleta, mas também pela "beleza" e "porte físico", entre outras qualidades que fogem do âmbito técnico-esportivo. Mas no 
segundo ano grande parte das meninas afirmou não ter ídolos e a professora se vangloria desse resultado identificando que trabalha o lado crítico do esporte, para não somente entender o esporte através do ídolo, já que não resgataria a verdadeira imagem esportiva.

Gráfico 02: Ídolos femininos

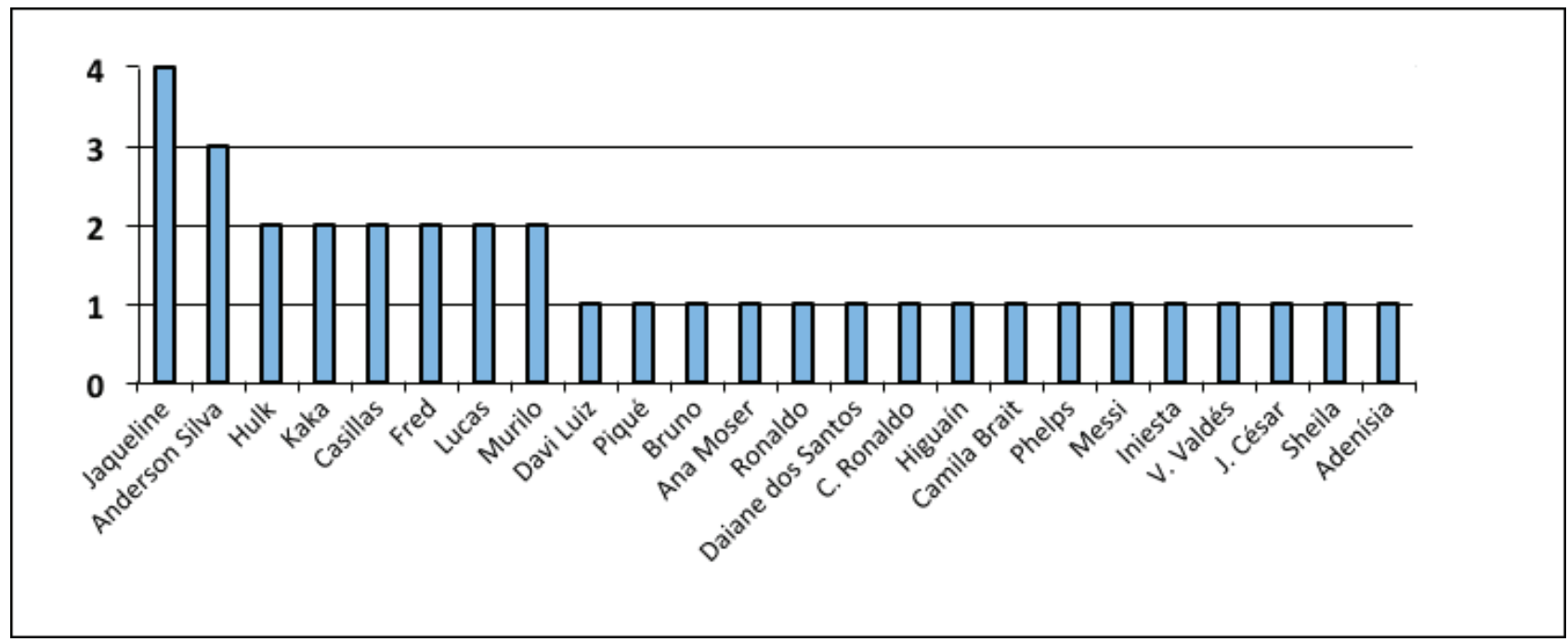

O gráfico 2 demonstra as escolhas das meninas quanto aos seus ídolos, em que Jaqueline (jogadora de vôlei) recebeu 4 votos, Anderson Silva ganhou três, logo em seguida vieram Hulk, Kaká, Casillas, Fred, Lucas e Murilo com dois votos (com exceção deste último, jogador de vôlei, os demais todos jogadores de futebol), com apenas um voto foram citados Davi Luiz, Piqué, Bruno, Ana Moser, Ronaldo, Daiane dos Santos (ginástica), Cristiano Ronaldo, Higuaín, C. Brait (vôlei), Phelps (natação), Messi, Iniesta, V. Valdés, J. César, Sheila e Adenísia (essas duas últimas do vôlei).

Percebemos o "culto à beleza" quando as entrevistadas citam e indicam figuras consideradas na mídia como ícones sexuais e bonitas, como Kaká, Casillas (goleiro da seleção espanhola de futebol), Fred, Cristiano Ronaldo e Júlio César. Além disso, Hulk (atacante da seleção brasileira de futebol) foi citado 2 vezes e uma delas diz ter um apreço pelo jogador devido à sua "bunda", que anda aparecendo tanto na mídia, chegando a fazer comparações com mulheres que são consideradas avantajadas.

Identificamos no trecho abaixo como a mídia observa a necessidade dos jovens e tenta transmitir significados em relação ao "corpo belo":

É evidente nos últimos anos, a preocupação que os jovens têm com seu corpo, esta realidade atinge não uma, mas todas as classes sociais; percebe-se também a grande influência dos meios de comunicação como formadores de opinião desses 
jovens sobre si mesmos. Cada vez mais os programas de televisão, revistas e jornais têm dedicado um espaço maior para mostrar novidades em setores de cosméticos, de alimentação e vestuário. Propagandas veiculadas estão o tempo todo tentando vender o que não está disponível em nossos dias: sucesso e felicidade (CRUZ; NILSON; PARDO; FONSECA, 2008, p. 2).

Existem também os atletas que foram citados devido à relação com o esporte que praticam ou pelo desempenho que têm, como Jaqueline (vôlei), Anderson Silva (MMA), Daiane dos Santos, Murilo (vôlei), Camila Brait (vôlei), Phelps (natação), Messi, Iniesta, Sheila e Adenísia (essas duas últimas da seleção brasileira feminina de vôlei).

Há, novamente, a relação de oferta-demanda que existe na mídia, os atletas citados, com exceção de Phelps e Daiane dos Santos, fazem parte dos principais esportes transmitidos atualmente: futebol, voleibol e MMA. Como encontramos em Sanfelice (2011), além de perceber o que se é necessário e lucrativo a ser consumido para prender o receptor, a mídia cria novas tendências a fim de manter e/ou renovar o mercado consumidor, sempre percebendo a necessidade individual.

Em outra questão investigada, solicitou-se que os sujeitos definissem as características que faziam os esportistas se tornarem ídolos para eles. As respostas de algumas meninas foram que "são os melhores", "ele têm uma aparência física muito boa", "são boas jogadoras, jogam na seleção e já ganharam vários campeonatos com os seus clubes", "admiro pela sua superação e por ser muito boa jogadora", "é um dos melhores goleiros da atualidade", "são atletas com histórias de superação e amor à profissão que me inspiram", "tenho grande admiração por seu desempenho no 'São Paulo' e por seu carisma e simplicidade”, "é um bom jogador, e tem a bunda avantajada. Não seria um ídolo, admiro ele".

Outro ponto importante que identificamos aqui é a própria relação da mídia na diferenciação de gênero, mais perceptível ainda quando se trata das mulheres retratarem os seus ídolos. Concordamos com Teixeira (2011) sobre a diferenciação entre as abordagens da Folha de São Paulo durante a LM (Liga Mundial) e o GP (Grand Prix), os dois sendo torneios de vôlei e respectivamente masculino e feminino. A pesquisa identificou que as reportagens que retratavam a LM apareciam em sua maioria mostrando fotos individuais e exprimindo força; já ao mostrar o GP, apareciam fotos de toda a seleção ou individualmente somente para mostrar o que entendiam como corpo belo. 
Gráfico 03: Ídolos masculinos

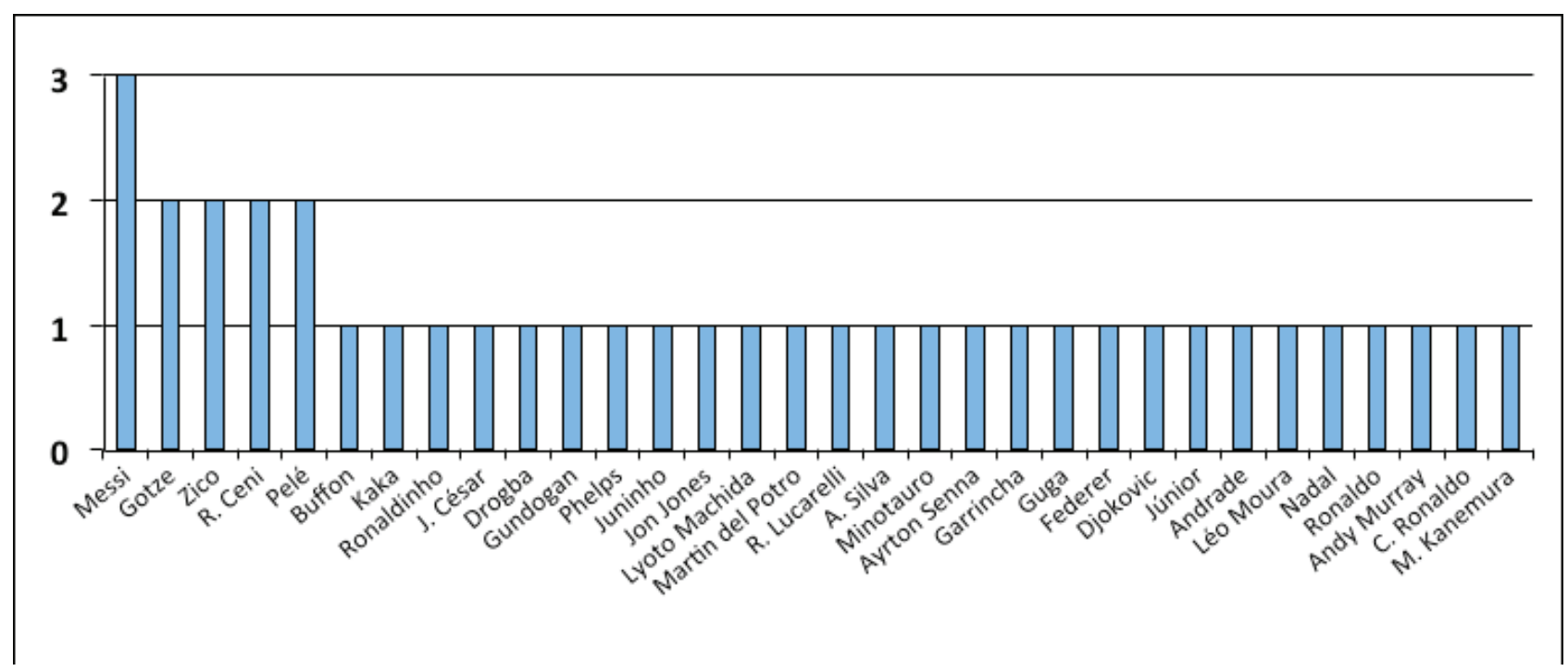

No caso dos meninos, identificamos que as escolhas dos ídolos se dá pela relação clubística ou identificação com o esporte que praticam, tanto para se parecerem com seus ídolos informados ou tentando identificar algo que possa ser "imitado", como identificamos na fala de Giglio (2007, p. 129): "O ídolo desempenha um papel importante na aproximação do clube com o torcedor. É ele quem faz o elo, quem aproxima a massa do espetáculo. Entre as formas que podem assumir essa aproximação, uma delas é a idolatria", e isso refere-se também ao gráfico 3 .

No gráfico anterior (3) foram citadas 23 pessoas consideradas "ídolos" pelos meninos pesquisados, sendo que os jogadores e ex-jogadores de futebol citados foram: Messi, mais votado com 3 votos; Gotze, Pelé, Zico e Rogério Ceni, com 2 votos cada; Garrincha, Júnior, Andrade, Léo Moura, Ronaldo e Cristiano Ronaldo com 1 voto. Todos os outros tiveram apenas um voto: do MMA, foram citados Jon Jones, Lyoto Machida, Anderson Silva e Minotauro. Com relação ao tênis, foram citados: Martin del Potro, Guga, Federer, Djokovic, Nadal e Andy Murray.

Coloca-se em "xeque" mais uma vez a relação midiática que existe nessa escolha, mesmo entendendo que alguns não foram acompanhados por eles devido à idade, mas sofrem também a influência dos pais ou até mesmo dos clubes que torcem, ao repassar sempre esses ídolos que representam o clube ou esporte de que mais gostam.

Agentes como a família, a escola, os amigos e a mídia, criando ídolos em forma de atletas, são determinantes na formação de demanda. Além disso, fatores como o conhecimento de oportunidades, custos associados, estatutos sociais do esporte, 
acessibilidade a instalações, são preponderantes na adequação da demanda (CLAEYS, 1987, apud CANAN; CALEGARI, 2006, p. 41).

Além disso, perceptível é que não foi citada nenhuma atleta como ídolo, isso se deve ao "foco" que dão às mulheres no esporte, dedicando, em sua maioria, a atenção ao corpo feminino e à beleza delas, uma vez que as escolhas dos alunos investigados se dão pelo lado esportivo. Outro ponto também é que o espaço midiático dado aos homens é muito maior, principalmente no futebol, em que o masculino é milionário e o feminino quase amador, como ratifica Goellner (2005).

Já com relação aos meninos, quando perguntados sobre as características que definem seus ídolos, algumas das respostas foram: "para mim o melhor goleiro do mundo, defende muito, é o cara, mito", "humildade, habilidades", "além de ser uma pessoa que joga na minha 'seleção' 'São Paulo Esporte Clube', é um cara com ótimo caráter, honra sua profissão”, "são ícones nos esportes", "bom de bola, humilde, contribui para a história do Vasco" e "a dedicação pelo seu esporte e a qualidade acima da média”.

[...] Os recordes alcançados pelos atletas, os títulos e as vitórias (e, mais do que isso, sua vontade e obsessão pelas conquistas) os tornam também genitores de uma criação. [...] Ao entrar em campo, de chuteiras, calção e com a camisa do seu clube, qualquer jogador de futebol parece incorporar uma dimensão mítica (MARQUES, 2002, p. 12-13).

Dentre as mais variadas respostas dos alunos, o que mais se assemelha aos ídolos e seus esportes, pode-se dizer, são as vitórias e conquistas que eles conseguem, isso que mais chama atenção para se tornar alvo da mídia. Fica assim perceptível que os alunos notam esse lado e fazem repercutir essa ideia para configurar os seus ídolos.

Gráfico 04: Por onde acompanham seus ídolos

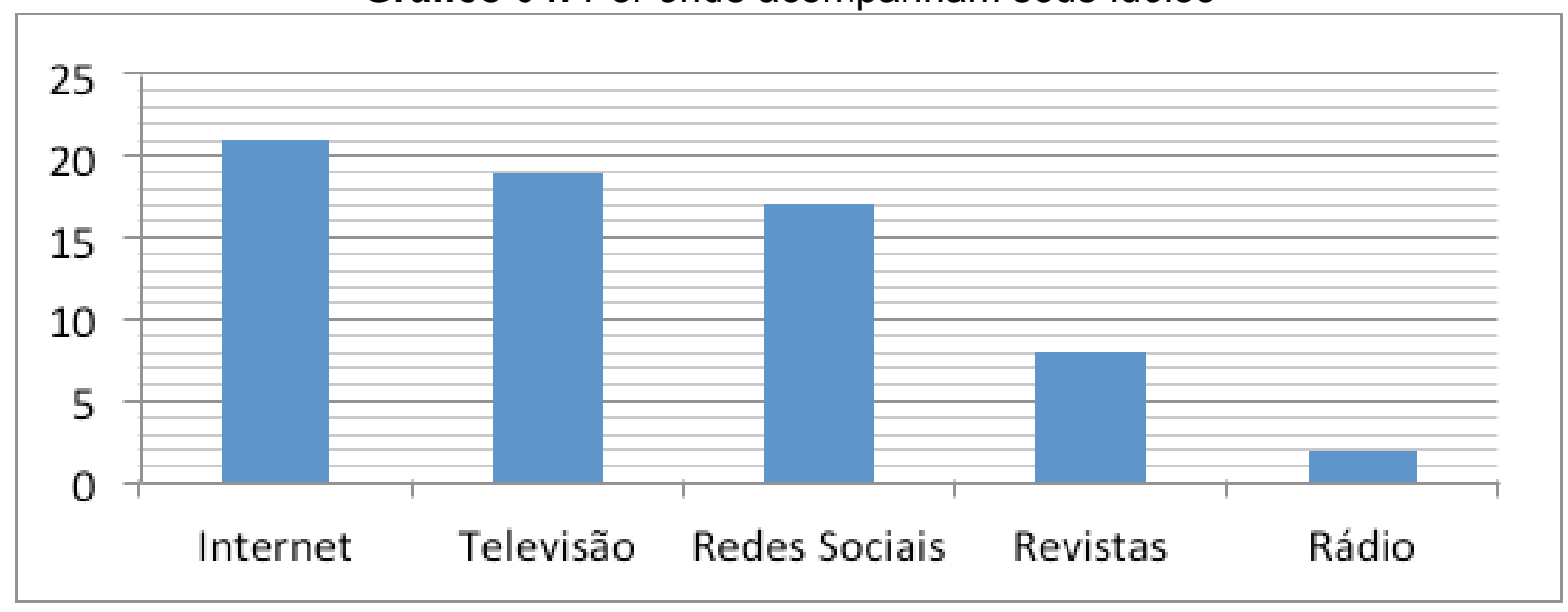


Investigou-se, também, por quais meios de comunicação de massa os alunos costumavam acompanhar seus ídolos. A partir do gráfico 04 , entendemos que fica válida a ideia de que as "novas mídias" estão em crescente aumento. Um ponto a ser especificado sobre essa questão é que identificamos que as redes sociais estariam inclusas na internet, mas quando falamos de internet em si, perguntou-se aos sujeitos quais os sites que costumam utilizar (sites de buscas, de fofocas, de revistas etc.). A internet foi citada por 21 alunos; a televisão recebeu 19; as redes sociais aparecem com 17 votos; revistas receberam 8 votos e rádio apenas 2 .

Esse resultado expõe que as mídias impressas e o rádio estão a cada dia mais esquecidos e desaparecendo, principalmente em se tratando do público jovem. A migração desses meios de comunicação para a internet faz com que, simultaneamente, sejam perdidos alguns adeptos, mas que seja atingida uma nova população. Percebemos que quem não faz essa "adaptação" acaba ficando para trás, como afirma Kepler (2012). As revistas, jornais e rádios podem ser vistos, lidos e ouvidos pela própria internet, já que são mídias que a cada dia mais perdem espaço para as "novas mídias". Além disso, apontamos a comodidade encontrada para se ter acesso à televisão e à internet, sem que seja preciso ter de pagar para se ver as notícias, principalmente para este grupo específico pesquisado, pois a própria escola dispõe de internet (wi-fi).

Outra questão que foi perguntada aos alunos foi se eles acompanhavam seus ídolos através das redes sociais. Houve uma disparidade com relação à questão anterior, pois apenas um aluno negou. Isso mostra a atual relação entre os atletas e o público. Rebustini et al, (2012) indicam que ferramentas como Twitter, Facebook, Instagram etc. só fazem crescer a idolatria e a possibilidade de acompanhar seus ídolos por 24 horas. A todo o momento surgem novas publicações e acontecimentos nas redes sociais desses ídolos, com o poder não só de informar, mas de se manter conectado, em contato com seus fãs.

Esse contato acaba gerando ainda mais a espetacularização/mercadorização esportiva, como podemos perceber no caso do próprio futebol, já que os jogadores, mesmo que não as gerenciem pessoalmente, têm páginas em redes sociais para que seus fãs possam acompanhar o dia-a-dia deles. Hoje em dia, um "curtir" se torna mais importante do que uma opinião gerada em alguma mídia! Então, como professores de EF, temos que entender 
e auxiliar os alunos no sentido da real compreensão do esporte, da mídia e do que é gerado neste "espetáculo".

Quando perguntamos aos sujeitos dessa pesquisa se eles adquirem ou não produtos relacionados aos seus ídolos, 10 alunos afirmaram que adquirem ou já adquiriram produtos. Na mesma questão pedimos que, caso a resposta à pergunta acima fosse afirmativa, informassem quais produtos eles adquiriram. As respostas foram por produtos como materiais esportivos, energético, protetor bucal, "Olympikus”. Já os outros 12 alunos que afirmam não possuir nenhum produto relacionado aos seus ídolos relacionam isto ao fato de entender não ser necessário gastar com esses produtos ("caros e desnecessários", "porque consigo discernir ídolo e fanatismo"), outros, deste mesmo grupo, se direcionam ao fato de não possuírem o poder aquisitivo, de não ter "condições" de comprar estes produtos, o que nos leva a crer que gostariam de adquirir, mas não o fazem ("por não ter dinheiro").

Com relação ao fato de terem uma ideia contrária ao consumismo, a professora B comenta que: "Assim tentamos esclarecer e discutir estas questões em sala de aula. Sempre discutimos sobre o que a mídia coloca para que as pessoas consumam, mas isto associando ao conhecimento que está sendo trabalhado especificamente".

Sobre a questão do consumo esportivo a partir das figuras dos ídolos e de suas paixões pelos clubes, às vezes beirando certo fanatismo, poderíamos afirmar que confirmase a ideia de que o agendamento e a espetacularização dão certo, como afirma Betti (1997, p.161):

[...] o esporte pode vender qualquer produto, e não apenas a si próprio. Por isso podemos, a princípio, dividir a propaganda em dois tipos: a que vende o próprio esporte, nos anúncios de tênis e outros materiais esportivos [...] e a que usa o esporte como tema, associando-o a produtos tão diversos como batatas fritas, pneus, perfume e equipamentos eletrônicos. (grifos do autor)

A constante aparição de atletas na mídia acaba por veicular produtos e significados para aqueles que os consideram ídolos esportivos. Essa associação acaba criando no receptor um "algo mais" por estar veiculado com os seus atletas preferidos e consumindo cada vez que pode. Isso se dá graças à mercadorização/espetacularização explicitada/denunciada por Pires (1998), que salienta o esporte e o que mudou devido à comercialização do mesmo. Desde que a "modernização" atraiu mais consumidores, maior tem sido a necessidade de 
se veicular produtos e a demanda por tais produtos, sendo os ídolos bravos representantes dessa mercadorização.

\section{Considerações Finais}

A pesquisa teve como objetivo analisar a possível influência da mídia na construção de ídolos esportivos, discutindo como estes são percebidos no universo dos jovens. As respostas dos alunos mostraram que a grande maioria deles gosta de esportes, praticandoos e/ou acompanhando modalidades esportivas.

Em ambas as turmas investigadas, o voleibol apareceu como esporte mais praticado - ultrapassando o futebol, que é o mais veiculado na mídia brasileira em geral ou até mesmo o esporte mais praticado em âmbito mundial, mesmo não tendo nenhum trabalho específico em torno do voleibol na escola pesquisada, conforme as falas das professoras. Sobre isso, Marchi Júnior (2005) acredita que o fato está em consonância com o processo de ressignificação do voleibol, tratado assim para expandir a presença do esporte na mídia, principalmente na televisão. Muitos outros esportes foram citados entre os mais praticados, como natação, tênis, handebol, basquete, futsal, entre outros.

Em relação aos esportes que os sujeitos investigados dedicam mais atenção, visualizamos uma inversão quanto ao esporte mais praticado, ou seja, se o voleibol, neste caso específico, apareceu como esporte mais praticado, o futebol apareceu como o esporte que mais acompanham no dia a dia. Segundo Canan e Calegari (2006), isso se dá devido ao maior espaço midiático do futebol. Mesmo a mídia "modificando" alguns esportes para que se tornem rentáveis e viáveis quanto à sua veiculação, no Brasil o futebol é inigualável quando se pensa em tempo de transmissão, veiculação, relação com publicidade e, consequentemente, lucratividade. A cada dia que passa, mais investimentos aparecem e as empresas, mesmo as que não têm vínculo nenhum com o esporte, percebem a oportunidade que há ali em vincular suas marcas, seus produtos e seus valores ao universo esportivo, principalmente ao universo futebolístico.

Os ídolos mais citados pelas alunas vão ao encontro dos três esportes mais veiculados atualmente, somente dois atletas não praticam futebol, vôlei ou MMA. Dos citados, a grande maioria foram atletas do futebol, mas os mais votados foram de outros esportes: Anderson 
Silva (lutador) e Jaqueline (jogadora de vôlei). Não deixamos de perceber que muitos dos atletas citados como ídolos são lembrados devido à aparência.

Entre os meninos, a maioria informou que têm um ou mais ídolos esportivos. Fica bastante claro entre eles que os escolhidos fazem parte do esporte que praticam ou têm relação com o clube pelo qual os sujeitos torcem. Conforme Kellner (2006), para afirmar essas ocorrências, a mídia cria um "culto ao atleta", junta situações do esporte para transformá-lo em verdadeiras celebridades a serem seguidas.

Uma questão que nos chamou atenção, mas que logo após o questionário respondido pelas professoras compreendemos melhor, foi o fato de Neymar não ser citado por nenhum dos alunos como ídolo. Com relação a esse grupo específico e o dado observado, concordamos com Pires (2007, p.9) ao relatar a necessidade de se ter a mídia como objeto de estudo e que muito se deu pelo trabalho desempenhado pelos professores em transmitir para os alunos a realidade existente nos esportes, não somente passar ao aluno o lado midiático ou reforçar o "estrelismo" em torno do atleta Neymar.

Sobre o relacionamento dos ídolos com os produtos do qual fazem propaganda, podemos perceber que houve um trabalho específico das professoras de EF em tentar transformar seus alunos em sujeitos "críticos" sobre o universo da cultura midiática e esportiva atual. Identificamos que os jovens pesquisados percebem, de certo modo, embora com muitas limitações, a mercadorização criada pela mídia para satisfazer os seus próprios anseios, dedicando e identificando estratégias para que, a partir da espetacularização esportiva, a midia amplie sua influência com a imagem e as representações dos ídolos (e não somente a eles), com a grande expectativa gerada sobre tais ícones esportivos (HELAL, 1999).

Também identificamos nas respostas dos alunos a presença da mediação pedagógica, mostrando que muitos acham ter consciência para distinguir o que realmente lhes é necessário quanto às questões do universo esportivo e seus "valores", que impactam na esfera do consumo em torno dos produtos, das necessidades e do que seus ídolos esportivos veiculam. Essa mediação pedagógica, tão importante e necessária, é percebida na fala de uma das professoras: "sempre discutimos sobre o que a mídia coloca para que as pessoas consumam, mas isto associando ao conhecimento que está sendo trabalhado especificamente" (PROFESSORA B). 
Concluímos, assim, que mesmo se tratando de um grupo específico que venha a sofrer uma influência do próprio colégio ao incitar nos alunos a perceberem a realidade e o que é imperceptível pela mídia, os jovens sofrem influência midiática na construção dos ídolos. Seja para manter os significados que querem impor por corpo belo, seja para estreitar a relação entre o clube e o torcedor, seja para vender produtos relacionados ou não ao esporte, seja para ampliar o olhar para determinado evento, o ídolo é um dos principais meios de manter a relação entre emissor-receptor quando se trata, principalmente, do aspecto mercadológico e lucrativo que se associa facilmente ao universo esportivo.

\section{Referências}

ASSIS, R.M.; VIEIRA, J.J. O trio de erre's e Felipão divulgados pela Folha de São Paulo. In: XXVI Congresso Brasileiro de Ciências da Comunicação, Belo Horizonte. Anais... Belo Horizonte: Sociedade Brasileira de Estudos Interdisciplinares da Comunicação, Núcleo de Pesquisa Mídia Esportiva, 2003.

BETTI, M. A janela de vidro: esporte, televisão e educação física. Tese (Doutorado em Educação), Universidade Estadual de Campinas, Campinas, 1997.

A janela de vidro: esporte, televisão e educação física. Campinas: Papirus, 1998.

. Esporte na mídia ou esporte da mídia. Motrivivência, Florianópolis, v.12, n.17, set. 2001. p.107-111.

O papel da Sociologia do Esporte na retomada da Educação Física, Revista bras. Educ. Fís. Esp., São Paulo, v.20, set. 2006, suplemento n.5, p.191-193.

BIANCHI, P.; HATJE, M. Mídia e esporte: os valores-notícia e suas repercussões na sociedade contemporânea. Motrivivência, n.27, dez. 2006.

BRACHT, V. A constituição das teorias pedagógicas da educação física. Caderno Cedes. Campinas, ano XIX, n.49, 1999, p.69-88.

CANAN, F.; CALEGARI, D.R. Fatores determinantes para a relação oferta/demanda do campo esportivo. Motrivivência, ano XVIII, n.27, dez. 2006, p.33-48.

CRUZ, P.P; NILSON, G; PARDO, E.R; FONSECA, A.O. Culto ao corpo: as influências da mídia contemporânea marcando a juventude. Fazendo Gênero 8 - Corpo, Violência e 
poder. Florianópolis, 2008. Disponível em: <http://www.fazendogenero.ufsc.br/8/sts/ST48/ Cruz-Nilson-Pardo-Fonseca_48.pdf> Acesso em: 11/07/2013

DEBORD, G. A Sociedade do Espetáculo. Rio de Janeiro: Contraponto, 1997.

FAUSTO NETO, A. O agendamento do esporte: uma breve revisão teórica e conceitual. Verso \& Reverso Revista da Comunicação, São Leopoldo: Unisinos, ano XVI, n.34, jan./ jun. 2002, p.9-17.

FERRES, J. Televisão e Educação. Porto Alegre: Artmed, 1996.

GASTALDO, E. "O país do futebol" mediatizado: mídia e Copa do Mundo no Brasil. Sociologias, Porto Alegre, ano 11, n²2, jul./dez. 2009, p.352-369.

GIGLIO, S.S. Futebol: Mitos, Ídolos e Heróis. Dissertação (Mestrado em Educação Física) - Universidade Estadual de Campinas, Campinas, 2007.

GOELLNER, S. V.Mulher e esporte no Brasil: entre incentivos e interdições elas fazem história. Revista Pensar a prática, Goiânia, v.8, n.1, 2005.

GRESSLER, L. A. Introdução à pesquisa: projetos e relatórios. 3 ed. São Paulo: Loyola, 2007.

HELAL, R. Mídia, Ídolos e Heróis do Futebol. Revista de Comunicação, Movimento e Mídia na Educação Física, Santa Maria, vol. 2, CEFD/UFSM, 1999.

KELLNER, D. Cultura da Mídia e triunfo do espetáculo. In: MORAES, D. de (org.) Sociedade midiatizada. Rio de Janeiro: Mauad, 2006, p. 119-147.

KEPLER, J. A mídia impressa x mídia digital. Disponível em: <http://joaokepler.blog. $\mathrm{br} / \mathrm{p}=458>$. Acesso em: 25 de agosto de 2013.

MARCHI JÚNIOR, W. O processo de ressignificação do voleibol a partir da inserção da televisão no campo esportivo. Revista Brasileira de Ciências do Esporte, Campinas, v.26, n.2, 2005, p.149-162.

MARQUES, J.C. A falação esportiva - o discurso da imprensa esportiva e o aspecto mítico sagrado do futebol. In: XXV Congresso Brasileiro de Ciências da Comunicação, 2002, Salvador. Anais... Salvador: Sociedade Brasileira de Estudos Interdisciplinares da Comunicação, Núcleo de Pesquisa Mídia Esportiva, 2002.

MEZZAROBA, C.; PIRES, G. L. O agendamento midiático-esportivo: considerações a partir dos Jogos Pan-Americanos Rio/2007. Logos, v.17, n.2, 2010, p.124-136. 
NEVES, J. L. Pesquisa qualitativa: características, usos e possibilidades. Cadernos de Pesquisas em Administração, v. 1, n.3, $2^{\circ}$ sem., 1996.

PIRES, G.L. O esporte e os meios de comunicação de massa: relações de parceria e tensão. Possibilidades de superação? In: GRUNENNVALDT, J.T.et al (org.). Educação física, esporte e sociedade: temas emergentes. São Cristóvão: Editora da UFS, vol. 1, 2007, p.1-10.

Breve introdução ao estudo dos processos de apropriação social do fenômeno esporte. Revista da Educação Física/UEM, Maringá, 1998, p.25-34.

REBUSTINI, F. et al. Novas mídias no esporte: um olhar sobre o twitter. Coleção Pesquisa em Educação Física, Rio Claro, vol.11, n.5, 2012, p. 71-78.

SANFELICE, G.R. Futebol, espetáculo e mídia: reflexões, relações e implicações. Características e valores veiculados em programas esportivos de televisão. Revista Comunicação, Movimento e Mídia na Educação Física, Santa Maria, v.6, n.7, 2001.

A construção midiática de Daiane dos Santos nos Jogos Olímpicos de Atenas 2004. Revista da Educação Física, Maringá, v.22, n.3, 2011.

TEIXEIRA, F.F. Gênero como fator de (in)diferenciação na mídia esportiva impressa: estudo da cobertura da participação das seleções brasileiras nas ligas mundiais de voleibol. 87p. Monografia (Trabalho de Conclusão de Curso em Educação Física) - Universidade Federal de Santa Catarina, Florianópolis, 2011. 


\section{THE INFLUENCE OF MEDIA IN THE CONSTRUCTION OF SPORTS IDOLS SPORTS FOR YOUTH}

ABSTRACT: Media, as a political agent has the capacity of creating behaviors. In that sense, we felt the need to observe how much young people can be influenced when we think about the relationship to sports idolatry. Thus, this study aims at analyzing the possible mediatic influence in the construction of sporting idols and how these are perceived in the youth universe. In order to achieve that we have selected students of the 1st and 2nd year of high school from a public school Sergipe (Brazil) for this research. From the results, we have been able to realize that, despite being a school where the pedagogical mediation is very important to understand and discuss the matters that involve media, we have been able to verify a strong media symbolic power, incorporating market meanings in the relationship between club-idol-supporter which also impact in the physical matter.

Keywords: media; sports idols; sporting spectacle; youth.

\section{LA INFLUENCIA DE LOS MEDIOS DE COMUNICACIÓN EN LA CONSTRUCCIÓN DE IDOLOS DEPORTIVOS DE LOS JÓVENES}

RESUMEN: Los medios masivos de comunicación como agente público tienen la capacidad de gestar comportamientos. Asumiendo esto, partimos de la necesidad de observar cuan influenciables son los jóvenes en relación a la idolatría deportiva. En este sentido, el objetivo de este estudio fue analizar la posible influencia de los medios de comunicación en la construcción de los ídolos del deporte y cómo se percibe en el mundo de los jóvenes. Para la investigación fueron seleccionados alumnos de primero y segundos años de la enseñanza media de una escuela pública federal de Sergipe, Brasil. A partir de los resultados obtenidos verificamos un fuerte poder simbólico mediático, incorporando significados mercadológicos en la relación club-ídolo-hincha que impactan también en la cuestión corporal.

Palabras-Clave: medios masivos de comunicación, ídolos deportivos, espectacularización deportiva, jóvenes. 